\title{
miR-19a Is Involved In Progression And Malignancy Of Anaplastic Thyroid Cancer Cells
}

This article was published in the following Dove Press journal: OncoTargets and Therapy

\author{
Giovanna Calabrese ${ }^{1, *}$ \\ Anna Dolcimascolol,* \\ Giuseppe Caruso $\mathbb{D}^{2}$ \\ Stefano Forte $\mathbb{1 D}^{3}$ \\ 'Department of Biomedical and \\ Biotechnological Sciences, Physiology \\ Section, University of Catania, Catania \\ 95123, Italy; ${ }^{2}$ Department of \\ Laboratories, Oasi Research Institute, \\ IRCCs, Troina, EN 940I8, Italy; \\ ${ }^{3}$ Molecular Biology Unit, IOM Ricerca, \\ Viagrande, CT 95029, Italy
}

*These authors contributed equally to this work
Correspondence: Giovanna Calabrese Department of Biomedical and Biotechnological Sciences, Physiology Section, University of Catania, Catania 95123 , Italy

Email giovanna.calabrese@unict.it

Stefano Forte

IOM Ricerca, Viagrande, CT 95029, Italy

Email stefano.forte@grupposamed.com
Background: MicroRNAs (miRNAs) are endogenous, single-stranded, non-coding RNAs acting as negative regulators of gene expression involved in a number of physiological processes. MiRNAs' expression is commonly dysregulated in many types of human tumor diseases and cancers, including thyroid cancers, and is often involved in tumor initiation and progression. miR-19a, a member of miR-17-92 cluster, has been demonstrated to promote cell growth in anaplastic thyroid cancer (ATC), the most advanced and aggressive thyroid cancer.

Purpose: In this work, we investigate the potential contribution of miR-19a in thyroid cancer cells poor prognosis and de-differentiation.

Methods: We directly modulated the expression of miR-19a in papillary (PTC) and anaplastic thyroid carcinoma cell lines through transfection of specific miR-19a mimic or inhibitor. Further, we performed gene expression analysis of specific genes to evaluate miR-19a association with cell cycle, differentiation, and poor prognosis.

Results: Our data indicate that miR-19a overexpression in PTC cells significantly promotes cell growth, decreases the expression of differentiation genes and activates poor prognosis genes. Its inhibition in ATC cells reduces cell proliferation and the expression of genes related to poor prognosis but does not affect differentiation.

Conclusion: Our findings reveal the existence of functional associations between miR-19a expression and thyroid cancer progression and malignancy suggesting miR-19a as a novel candidate therapeutic target for ATC.

Keywords: cluster miR-17-92, miR-19a, thyroid carcinoma, poor prognosis, differentiation

\section{Introduction}

MiRNAs are an evolutionarily well-preserved class of endogenous small non-coding RNAs (19-25 nt) that negatively control gene expression and play crucial roles in regulating several cellular and biological processes including cell proliferation, differentiation, apoptosis, and metabolism. ${ }^{1-5}$ Recent studies have also demonstrated that miRNAs deregulation considerably relates with the initiation and progression of numerous human tumors, such as colorectal cancer, ${ }^{6} \mathrm{~B}$ cell chronic lymphocytic leukemia, ${ }^{7}$ lung cancer, ${ }^{8}$ breast cancer, ${ }^{9}$ glioblastoma, ${ }^{10}$ prostate cancer, ${ }^{11}$ gastric cancer $^{12}$ and thyroid carcinoma. ${ }^{13}$ Over 2500 miRNAs have been identified in humans so $\operatorname{far}^{14}$ and approximately $50 \%$ of the human miRNA genes are frequently located at fragile sites and genomic regions involved in cancers. ${ }^{15}$ Numerous tumor-associated miRNAs show oncogenic activity, ${ }^{16}$ while others that are negatively regulated in neoplastic cells act as tumor suppressors. ${ }^{17}$

MiR-17-92, a well-known polycistronic miRNA cluster, comprises six different miRNAs (miR-17, miR-18a, miR-19a, miR-20a, miR-19b-1, and miR-92a). Ota 
et al, in 2004, have identified the oncogenic role of this cluster in dispersed large B cell lymphomas of repeated focal amplifications. ${ }^{18}$ It has been demonstrated that miR17-92 cluster may be involved in stimulating proliferation and malignancies also in solid human tumors such as small-cell lung tumor, colon tumor, neuroblastoma, medulloblastoma and gastric cancer. ${ }^{19-21}$

Although miR-17-92 members all belong to the same family, they may act both as part of the same pattern or independently. Specifically, miR-17-5p is a key regulator of the G1/S phase cell cycle transition and target more than 20 genes involved in this transition; ${ }^{22}$ miR-17-3p induces cell death and exacerbation of oxidative stress in human retinal pigment epithelial (ARPE-19) cells; ${ }^{23}$ miR-17-5p and miR17-3p are strongly overexpressed in clinical ATC samples compared to healthy tissue ${ }^{24}$ miRNA-17, miRNA-18a, and miRNA-19a act as oncogenes and may play a role in the process of esophageal squamous cell carcinoma (ESCC); ${ }^{25}$ miR-20a acts as tumor promoter in colorectal cancer ${ }^{26}$ and as tumor suppressor in anaplastic thyroid cancer. ${ }^{27}$ In addition, Olive et al demonstrated that miR-19 is a key oncogenic element of mir-17-92 family promoting cell survival by activating the Akt-mTOR pathway and antagonizing Pten. $^{28}$

Thyroid tumors represent the most prevalent and incident type of endocrine neoplasia, accounting for approximately $1 \%$ of all new cases diagnosed each year. ${ }^{29,30}$ Data show how hereditary conditions, ${ }^{31}$ along with gender and age, ${ }^{32}$ low-iodine diet, ${ }^{33}$ and radiation exposure, ${ }^{34}$ play a significant role in the incidence of thyroid tumors. Thyroid tumors can be classified in differentiated (up to approximately $90 \%$ of all thyroid tumors), including PTC and FTC, and undifferentiated, such as ATC. ${ }^{35}$ Unlike PTC and FTC patients, ATC patients have poorer prognosis and reduced overall survival. ${ }^{36}$

Our group recently demonstrated that miR-19a overexpression in FTC-133 cell line induces a more de-differentiated and aggressive phenotype. ${ }^{37}$ In this study, we aim to confirm the role of mir-19a overexpression in thyroid cancer progression and malignancy by using another welldifferentiated cell line, PTC, showing a miR-19a expression level lower than FTC. In addition, to further support the mir-19a function in promoting tumor progression, we evaluated the effect of its inhibition in ATC cell line, which expresses higher basal level than PTC and FTC. To this end, we evaluated the impact of miR-19a modulation on cell morphology, proliferation, viability, apoptosis, and gene expression after miR mimic/inhibitor transfection.
Our findings suggest a causative role of miR-19a in the maintenance of the undifferentiated state typical of ATC, thus contributing to its associated aggressiveness and clinical outcome, according to its direct impact on downstream molecular pathways in vitro. Further, the modulation of poor prognosis genes may also support its involvement in the development of more effective therapies for the treatment of thyroid cancer.

\section{Materials And Methods Cell Culture}

Three human thyroid cancer cell lines FTC-133 (SigmaAldrich, Italy), K1 (Sigma-Aldrich, Italy), and 8505c (Sigma-Aldrich, Italy) were used in this study. FTC-133 cells were cultured in DMEM: Ham's F12 (1:1) (SigmaAldrich, Italy) supplemented with L-Glutamine $2 \mathrm{mM}$ (Euroclone, Italy), penicillin/streptomycin/amphotericin (PSA) (Euroclone, Italy), and 10\% Fetal Bovine Serum (FBS) (Sigma-Aldrich, Italy). K1 cells were cultured in DMEM: Ham's F12: MCDB 105 (2:1:1) (Sigma-Aldrich, Italy) supplemented with L-Glutamine $2 \mathrm{mM}$ (Euroclone, Italy), penicillin/streptomycin/amphotericin (PSA) (Euroclone, Italy), and 10\% Fetal Bovine Serum (FBS) (Sigma-Aldrich, Italy), while for $8505 \mathrm{c}$ cells, the medium employed was EMEM (Sigma-Aldrich, Italy) containing $1 \%$ of nonessential amino acids, L-Glutamine $2 \mathrm{mM}$, PSA, and $10 \%$ FBS. Cells were maintained in a humidified environment at $37^{\circ} \mathrm{C}$ and $5 \% \mathrm{CO}_{2} / 95 \%$ air atmosphere and cultured in $75 \mathrm{~cm}^{2}$ culture flasks. The medium was replaced twice a week and cells were split at about $80-90 \%$ of the confluence.

\section{Transfection Of KI And 8505C Cells By Synthetic miRNA Mimic Or Inhibitor}

In order to modulate miR-19a expression, $\mathrm{K} 1$ and $8505 \mathrm{c}$ cells were transfected with specific mirVana miRNA mimic/ miRNA inhibitor (hsa-miR-19a-p3; Life Technologies, Camarillo, CA, USA) in accordance with the manufacturer's instructions. Briefly, both Lipofectamine RNAiMAX reagent (Thermo Fisher Scientific, Italy) and miRNA (10 $\mu \mathrm{M}$ initial concentration) were diluted in Opti- MEM Medium (Thermo Fisher Scientific, Italy). The diluted miRNA solution was added to an equal volume of diluted Lipofectamine RNAiMAX reagent (1:1 ratio) and the resulting solution was incubated for $5 \mathrm{mins}$ at room temperature. $\mathrm{K} 1$ and $8505 \mathrm{c}$ cells at the appropriate confluence $(\sim 70 \%)$ were detached, counted, and $0.25 \times 10^{6}$ cells $/ 6$-well transfected 
with the miRNA-lipid complexes (miRNA mimic/inhibitor final concentration $0,1 \mu \mathrm{M})$. Finally, transfected cells were maintained in a humidified environment at $37^{\circ} \mathrm{C}$ and $5 \%$ $\mathrm{CO} 2 / 95 \%$ air atmosphere for 24, 48, and $72 \mathrm{hrs}$.

For all experiments, cells transfected only with the transfecting agent were used as control. The morphological changes of $\mathrm{K} 1$ and 8505 c cells after miR-19a modulation were assessed and acquired using a Leica DMI 4000B microscope (Leica, Wetzlar, Germany).

\section{Measurement Of Cell Proliferation Through DAPI Staining}

For DAPI staining, 24 and $48 \mathrm{hrs}$ after miR mimic and miR inhibitor transfection, the cells were fixed in $4 \%$ PFA for 15 mins and permeabilized in $0.3 \%$ Triton X-100 for 5 mins. The cells were washed 3 times with PBS and the nuclei counterstained with DAPI $(1: 5000)$ in PBS for 5 mins. Slides were mounted in fluorescent mounting medium Permafluor (Thermo Scientific) and digital images were acquired using a Leica DMI4000B fluorescence microscope. At least five images from each sample were taken for the count. Cell count analysis has been performed using Fiji image recognition software.

\section{Measurement Of Cell Viability Through MTT Assay}

The cell viability of $\mathrm{K} 1$ and $8505 \mathrm{c}$ cells, treated with both only transfecting agent and $\mathrm{miR} \mathrm{mimic} / \mathrm{miR}$ inhibitor, respectively, was evaluated by MTT [3-(4,5-dimethylthiazol-2-yl)-2,5-diphenyltetrazolium bromide] (SigmaAldrich, Italy) assay. Specifically, 24 and 48 hrs after cell transfection, the medium from each well was removed and replaced with $200 \mu \mathrm{L}$ of MTT solution $(1 \mathrm{mg} / \mathrm{mL}$ in FBSfree medium). Following $2 \mathrm{hrs}$ incubation at $37^{\circ} \mathrm{C}$ and $5 \%$ $\mathrm{CO}_{2}$, MTT solution was removed, each well was washed 2 times using cold PBS $0.01 \mathrm{M}$, and the formed crystals were melted using $200 \mu \mathrm{L}$ of DMSO. Next, the absorbance at $570 \mathrm{~nm}$ was read using a synergy HT plate reader (BioTek Instruments, Inc., VT, United States).

\section{Measurement Of Caspase-3/-7 And Caspase-9 Activity}

Briefly, the Caspase-Glo ${ }^{\circledR} 3 / 7$ or 9 Buffer and lyophilized Caspase-Glo ${ }^{\circledR} 3 / 7$ or 9 Substrate (Promega, Milan, Italy) as well as the 96-well plates containing cells were equilibrated at room temperature (10 mins). The content of the Caspase-Glo $^{\circledR} 3 / 7$ or 9 Buffer was transferred into the bottle containing Caspase-Glo ${ }^{\circledR} 3 / 7$ or 9 Substrate and mixed by inverting the contents. Fifty microliters of the resulting solutions were added to an equal volume of each sample, the contents of wells were gently mixed using a plate shaker at $500 \mathrm{rpm}$ for $1 \mathrm{~min}$, and the plates were left to incubate at room temperature for $1 \mathrm{hr}$. Blank reaction consisting of Caspase-Glo ${ }^{\circledR} 3 / 7$ or 9 Reagent and vehicle was used as a control. The luminescence of each sample was read using a synergy HT plate reader (BioTek Instruments).

\section{qRT-PCR}

For qRT-PCR analyses, total RNA from K1 and 8505c cells was isolated 24, 48, and $72 \mathrm{hrs}$ post-transfection using RNeasy Mini Kit (Qiagen, Germantown, MD, USA) and quantified as previously described. ${ }^{38,39}$ Three independently isolated and cultured samples were used for each of the 3 time points. cDNA was synthesized from $1 \mu \mathrm{g}$ of total RNA using ImProm-II Reverse Transcription System (Promega, Milan, Italy). qRT-PCR was performed using SYBR Green method on a 7900HT Real-Time PCR using manufacturer's protocol (Applied Biosystems). Specific primers for each of the investigated molecular endpoint were designed using primer blast and selecting exon-exon junctions on mRNA as target region for annealing. Each sample was tested in triplicate and gene expression was assessed using the $2^{-\Delta \Delta \mathrm{Ct}}$ method. RNA from untreated cells was used as reference for relative expression quantitation. The following primers for qRT-PCR were used: CDH1 (Cadherin-1), S100A4 (S100 calcium-binding protein A4), STK-5 (Serine/threonine-protein kinase hal4), Tg (Thyroglobulin 1), Pax8 (Paired box 8), TSHr (thyroid-stimulating hormone receptor), and TTF1 (transcription terminator factor). Oligonucleotide sequences are reported in Supporting table 1. Glyceraldehyde 3-phosphate dehydrogenase (GAPDH) has been used as reference gene. Expression Suite Software v1.1 has been used for data analysis.

The expression levels of miR-19a in $\mathrm{K} 1$ and $8505 \mathrm{c}$ after its overexpression/inhibition have been calculated as described by Yang et al. ${ }^{40,41}$

Primer sequences were presented as following: miR-19a, RT: 5'-GTCGTATCCAGTGCAGGGTCCGAGGTATTCGC ACTGGATACGACTCAGTTT-3'; Forward: 5'-CTGGAGT GTGCAAATCTATGC-3'; Reverse: 5'- GTGCAGGGTCCG AGGT-3'; U6, RT: 5'-AAAATATGGAACGCTTCACGAAT TTG-3'; Forward: 5'-CTCGCTTCGGCAGCACATATACT3'; Reverse: 5'-ACGCTTCACGAATTTGCGTGTC-3'. 
The relative expression level of miR-19a was calculated using $2^{-\Delta \Delta \mathrm{Ct}}$ method, with the $\mathrm{CT}$ values normalized using $\mathrm{U} 6$ as an internal control.

\section{Statistical Analysis}

Statistical analyses were performed by one-way ANOVA. Tukey HSD (Honestly Significant Difference) method has been used as post hoc test when the ANOVA reported statistically significant differences to evaluate the differences between the individual time-points or treatment groups.

\section{Results}

\section{MiR-I9a Is Expressed At Very Low Levels In PTC Compared To FTC And ATC}

To quantitatively assess the miR-19a basal levels in PTC and ATC compared to FTC we performed qRT-PCR on total RNA isolated from K1, FTC-133, and 8505c cells. MiR-19a expression levels of PTC and ATC have been compared to FTC and normalized on the control U6 snRNA.

The assessment of miR-19a basal expression, performed by qRT-PCR, indicates that $\mathrm{K} 1$ cells produce significantly lower level of mature miR-19a while 8505 c cells higher than FTC-133 cells (K1/FTC-133 RQ $=0,077893938$, $* * \mathrm{p}<0.01 ; \quad 8505 \mathrm{c} / \mathrm{FTC}-133 \quad \mathrm{RQ}=\quad 3,270,828,071$, $* * p<0.01)$. Post-transfection logarithmic RQ values are reported in Figure 1A.

\section{MiR mimic/Inhibitor Modulates miR-19a Expression Levels Up To 48 hrs}

To evaluate miR-19a expression levels after miR mimic and inhibitor transfection on $\mathrm{K} 1$ and $8505 \mathrm{c}$, respectively, we utilized qRT-PCR. MiR-19a expression at 24, 48, and 72 hrs from activation and inhibition was compared to miRNA levels of control groups and normalized to the control U6 snRNA. Our data showed that miRNA levels of miR-19a overexpressing $\mathrm{K} 1$ cells, at each time point, were higher than control cells (K1+M_24 hrs: $12.3 \pm 0.278,{ }^{* *} \mathrm{p}<0.01$; $\mathrm{K} 1+\mathrm{M} \_48 \mathrm{hrs}: 15.7 \pm 0.478,{ }^{* *} \mathrm{p}<0.01 ; \mathrm{K} 1+\mathrm{M} \_72 \mathrm{hrs}: 2.51$ $\pm 0.117, \mathrm{p}=0.2)$ even if $\mathrm{K} 1+\mathrm{M} \_72 \mathrm{hrs}$ showed no statistically significant trend (Figure 1B). On the other hand, $8505 \mathrm{c}$ cells transfected with the miR-19a inhibitor showed a statistically significant decrease of expression levels compared to control cells only at 24 and $48 \mathrm{hrs}\left(8505 \mathrm{c}+\mathrm{I} \_24 \mathrm{hrs}\right.$ : $0.265 \pm 0.032, * * p<0.01 ; 8505 \mathrm{c}+\mathrm{I} \_48 \mathrm{hrs}: 0.178 \pm 0.003$, $* * \mathrm{p}<0.01$ ), while at $72 \mathrm{hrs}$, expression level was slightly upregulated, exceeding the baseline expression level, in a statistically significant manner $(1.60 \pm 0.102, * * p<0.01)$ (Figure 1C). These losses of effect of both mimic and inhibitor at $72 \mathrm{hrs}$ from transfection suggest that the effect of miR-19a modulation cannot be assessed after $48 \mathrm{hrs}$. For this reason, we decided to evaluate the cellular and molecular aspects of miR-19a modulation only until $48 \mathrm{hrs}$ after transfection.

\section{Mir-19a Overexpression On KI Increases Cell Viability And Proliferation}

To investigate the effect of mir-19a mimic overexpression on K1 cells, we analyzed cell morphology, proliferation, and viability at 24 and 48 hrs post-transfection (Figure 2).

Upon morphological analysis, we did not observe any significant phenotypic differences (Figure 2A), but an increased proliferation on miR-19a mimic overexpressing $\mathrm{K} 1$ cells, at both evaluated time points, 24 and $48 \mathrm{hrs}$, compared to the control (Figure 2D).

Cell viability on miR-19a overexpressing and control $\mathrm{K} 1$ cells, at 24 and $48 \mathrm{hrs,}$, was evaluated by MTT assay. Our data showed a statistically significant increase in cell viability at both $24(20 \% \pm 0.033, \mathrm{p}=0.01)$ and $48 \mathrm{hrs}(20 \%$ $\pm 0.008, \mathrm{p}=0.03$ ) versus the control cultures (Figure $2 \mathrm{~B}$ ).

According to morphological analysis, nuclei count, performed on K1 cells transfected by miR-19a mimic, showed a significant increase of cell proliferation at both time points ( 24 and $48 \mathrm{hrs)} \mathrm{compared} \mathrm{to} \mathrm{the} \mathrm{control} \mathrm{cells}$ ( $\mathrm{p}=0.01$ at both 24 and $48 \mathrm{hrs}$ ) (Figure 2C and D).

\section{Mir-19a Inhibition On 8505c Reduces Cell Viability And Proliferation}

To clarify whether mir-19a exerts specific functions on ATC cells, we analyzed cell morphology, viability, and proliferation at 24 and $48 \mathrm{hrs}$ from its inhibition.

Analogously to the K1 cell line, the morphological analysis of 8505 c cells after miR-19a inhibition showed no significant phenotypic change when compared to control cells (Figure 3A) at both analyzed time points (24 and $48 \mathrm{hrs}$ ). On the other side, a significant reduction of cell proliferation was visible in miR-19a downregulating 8505 c cells (Figure $3 \mathrm{C}$ and D).

MTT assay performed on 8505c cells after miR-19a inhibition displayed a statistically significant decrease of cell viability compared to control cultures at both examined time points, specifically at $24(18 \% \pm 0.0087, \mathrm{p}=0.05)$ and $48 \mathrm{hrs}(24 \% \pm 0.0085, \mathrm{p}=0.008)$ (Figure $3 \mathrm{~B})$. 

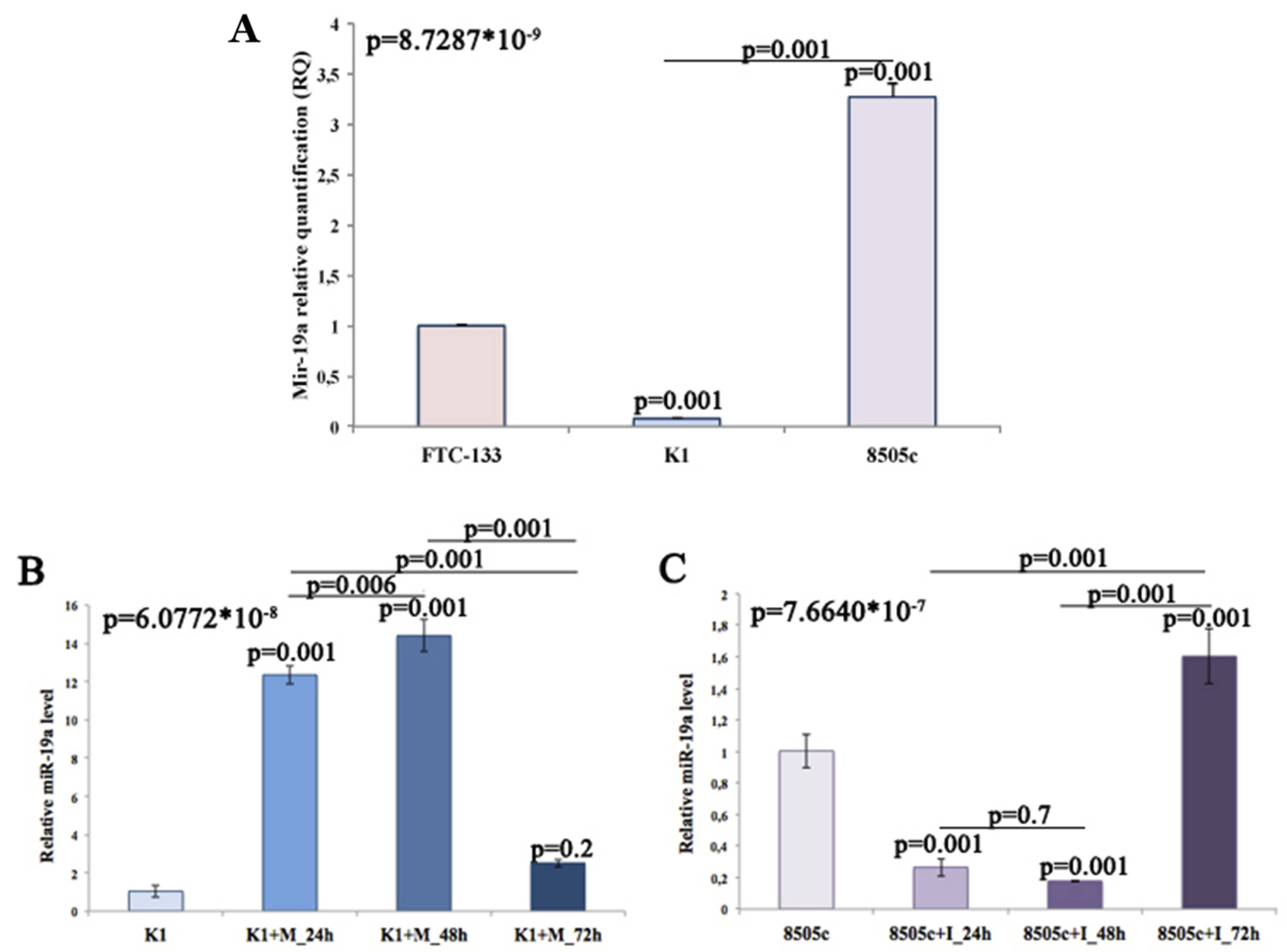

Figure I Quantification of miR-19a expression levels. (A) Quantitation of miR-19a basal level in three different thyroid cancer cell lines. FTC-I33 cells have been used as control group. (B and C) Quantitation of relative miR-19a expression levels time course, using KI and $8505 \mathrm{c}$ untreated cells as control groups.

The cell proliferation assay (Figure 3C) showed a significant decrease in cell growth in $8505 \mathrm{c}$ downregulating miR-19a cells only at $48 \mathrm{hrs}$, compared to the control cells $(\mathrm{p}=0.001)$ (Figure 3D).

\section{KI And 8505c Cells Have An Opposing Effect On Apoptosis After miR-I 9 Up-/ DownRegulation}

To evaluate the effect of miR-19a mimic overexpression on apoptotic processes, we performed Caspase 3/7 and Caspase 9 analyses at 24 and $48 \mathrm{hrs}$ after transfection in both $\mathrm{K} 1$ and $8505 \mathrm{c}$ cells. Our data showed that there is no activation of Caspase 3/7 in K1 cells after miR-19a overexpression (Figure 4A) at both time points. Caspase 9 levels significantly decrease at both 24 and $48-\mathrm{hr}$ time points on $\mathrm{K} 1$ cells overexpressing miR-19a (Figure 4B; $24 \mathrm{hrs} p=0.01 ; 48 \mathrm{hrs} p=0.001$ ). The analyses of Caspase
$3 / 7$ and 9 levels in 8505 c cells after miR-19a inhibition at 24 and 48 hrs showed significantly increased levels after $48 \mathrm{hrs}$ from inhibition (Figure 4C; Caspase 3/7, p=0.001 and Figure 4D; Caspase 9, $\mathrm{p}=0.002$ ).

\section{MiR-19a Modulation In KI And 8505c Cells Alters Their Gene Expression Profile Related To Cell Cycle, Differentiation, And Poor Prognosis}

To better evaluate the effect of miR-19a modulation on K1 and $8505 \mathrm{c}$ cells, the expression levels of cell cycle genes, such as Cell Division Cycle 25A (CDC25a), Aurora Kinase B (STK5), thyrocyte-specific markers, including Thyroid-Stimulating Hormone receptor (TSHr), Thyroglobulin (Tg), Transcription Termination Factor 1 (TTF1), Paired Box Gene 8 (Pax8), and poor prognosisrelated genes, such as Cadherin-1 (CDH1) and S100 

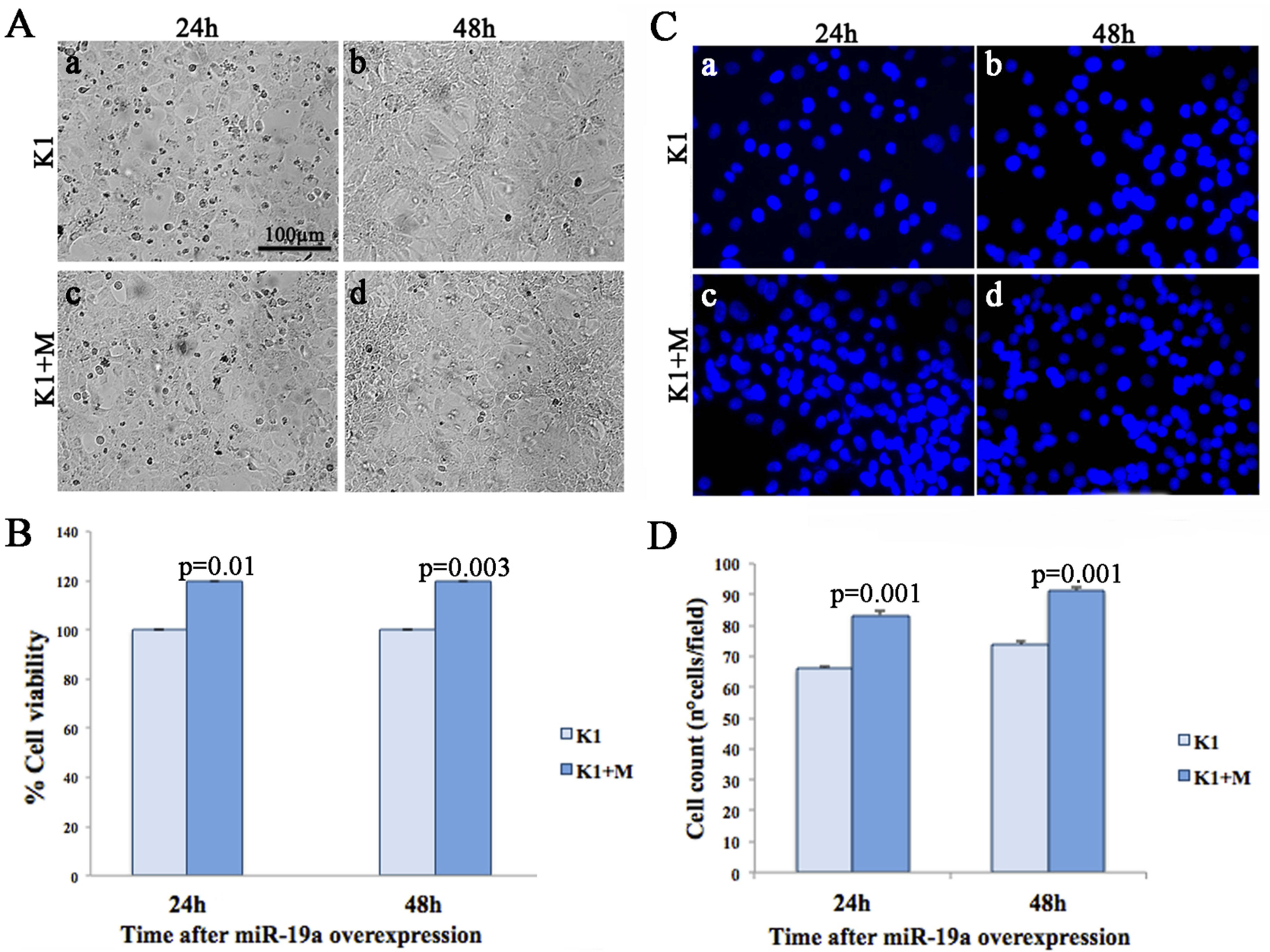

D

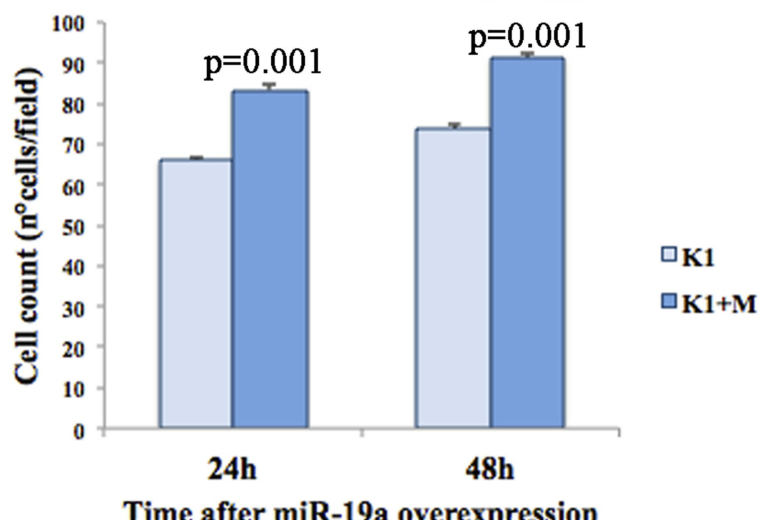

Figure 2 Effects of miR-19a overexpression on KI cell morphology, proliferation, and viability. (A) Morphological analysis of control (a-b) and miR-19a mimic transfected cells (c-d). (B) Cell viability, assessed by MTT, of $\mathrm{KI}$ and $\mathrm{KI}+\mathrm{M}, 24$ and 48 hrs post-miR-19a overexpression. (C) Representative DAPI images showing the increase in cell growth upon miR-19a mimic overexpression (c, d) compared to control (a, b). (D) Average nuclei count in control (light blue) and miR-19a mimic transfected cells (blue) after 24 and 48 hrs.

calcium-binding protein A4 (S100A4), and have been analyzed (Figures 5 and 6).

Our data obtained on K1 cells after miR-19a mimic overexpression displayed a significant marked upregulation of CDC25a at both time points compared to the control and between the two time points (Figure $5 \mathrm{~A} ; 24$ $\mathrm{hr} / \mathrm{ctr}$ and $\left.48 \mathrm{hr} / \mathrm{ctr}_{-}{ }^{* *} \mathrm{p}<0.01 ; 48 \mathrm{hrs} / 24 \mathrm{hrs}{ }_{-}^{* *} \mathrm{p}<0.01\right)$. On the other hand, STK5 showed a significant increase only at $24 \mathrm{hrs}$ and a decrease to $48 \mathrm{hrs}$ compared to both control and time $24 \mathrm{hrs}$ (Figure $5 \mathrm{~A}, 24 \mathrm{hr} / \mathrm{ctr}_{-}{ }^{*} \mathrm{p}=<0.05$; $\left.48 \mathrm{hr} / \mathrm{ctr} \_\mathrm{p}=0.5,48 \mathrm{hrs} / 24 \mathrm{hrs}{ }_{-}{ }^{*} \mathrm{p}<0.01\right)$

K1 cells overexpressing miR-19a showed a statistically significant downregulation of all genes promoting the differentiation of thyroid cells over time (Figure 5B). Particularly, Tg and Pax8 expression levels were significantly downregulated, from $24 \mathrm{hrs}$ to $48 \mathrm{hrs}$ ((Figure 5B; $24 \mathrm{hr} / \mathrm{ctr}$ and $\left.48 \mathrm{hr} / \mathrm{ctr}_{-}{ }^{* *} \mathrm{p}<0.01\right)$ compared to the control. Moreover, K1 cells overexpressing miR-19a, 48 hrs after transfection, exhibited also a statistically significant downregulation compared to the $24 \mathrm{hrs}$ ((Figure 5B; $\left.48 \mathrm{hr} / 24 \mathrm{hr}{ }^{* *} \mathrm{p}<0.01\right)$. TSHr expression levels showed a statistically significant downregulation at each time point compared to the control group ((Figure 5B; 24 $\mathrm{hr} / \mathrm{ctr}$ and $\left.48 \mathrm{hr} / \mathrm{ctr}_{-}{ }^{* *} \mathrm{p}<0.01\right)$, more marked at $24 \mathrm{hrs}$ ((Figure 5B; $\left.48 \mathrm{hr} / 24 \mathrm{hr}_{-}{ }^{* *} \mathrm{p}<0.01\right)$.

The analysis of the TTF1 expression profile showed no variation at $24 \mathrm{hrs}$ and a significant downregulation only at $48 \mathrm{hrs}$ ((Figure 5B; $\left.48 \mathrm{hr} / \mathrm{ctr}_{-}{ }^{* *} \mathrm{p}<0.01\right)$.

The expression profile of poor prognosis-related genes evaluated on $\mathrm{K} 1$ cells overexpressing miR-19a mimic displayed a marked downregulation for $\mathrm{CDH} 1$ at each analyzed time point only compared to the control (Figure 5C; $24 \mathrm{hr} / \mathrm{ctr}$ and $\left.48 \mathrm{hr} / \mathrm{ctr}_{-}^{* *} \mathrm{p}<0.01\right)$. S100A4 showed an upregulation at 24 and $48 \mathrm{hrs}$, statistically significant only at $24 \mathrm{hrs}$ compared to the control (Figure 5C; $24 \mathrm{hr} / \mathrm{ctr}_{-}{ }^{* *} \mathrm{p}<0.01$ ). 

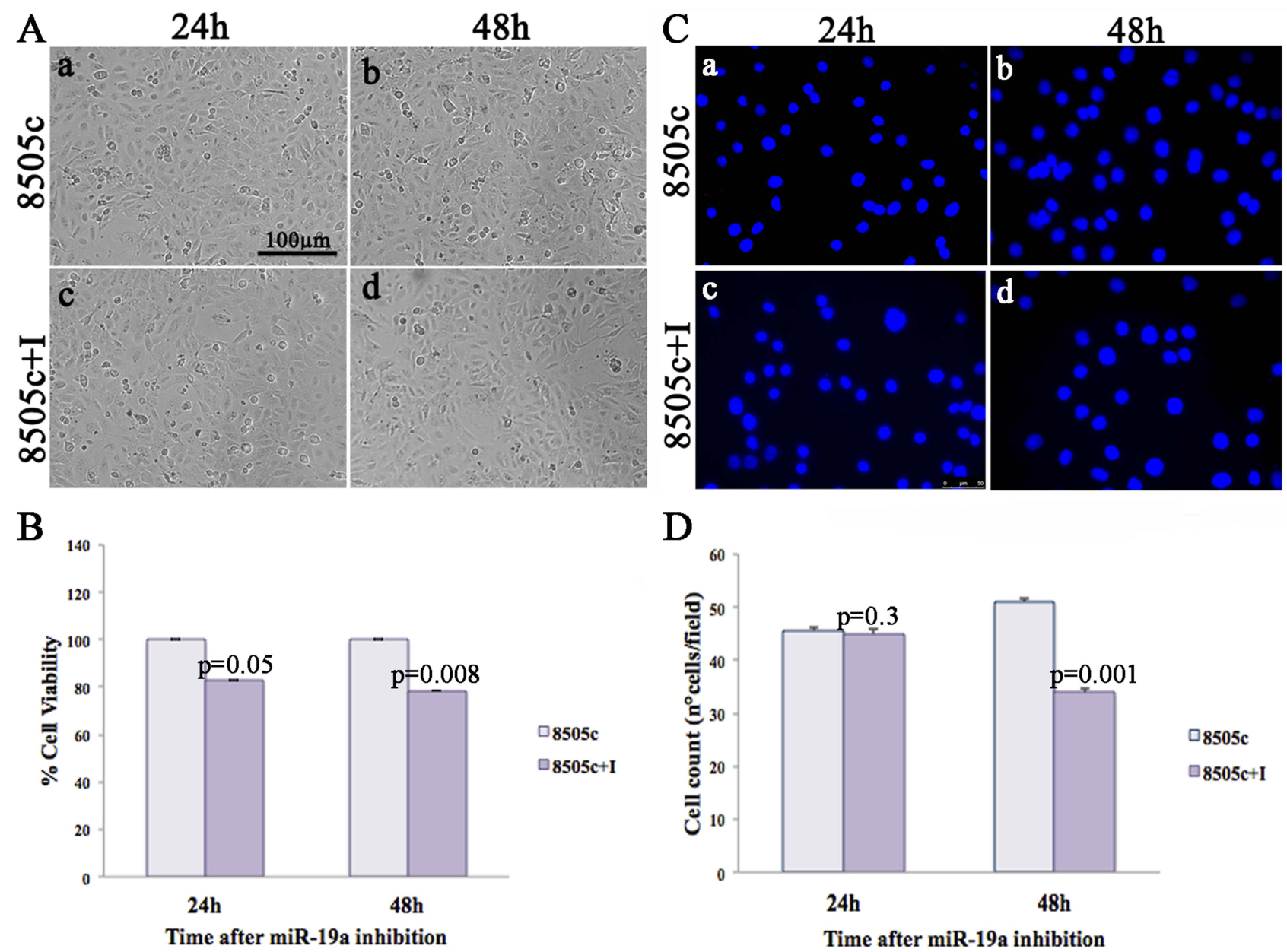

\section{$\mathrm{D}$}

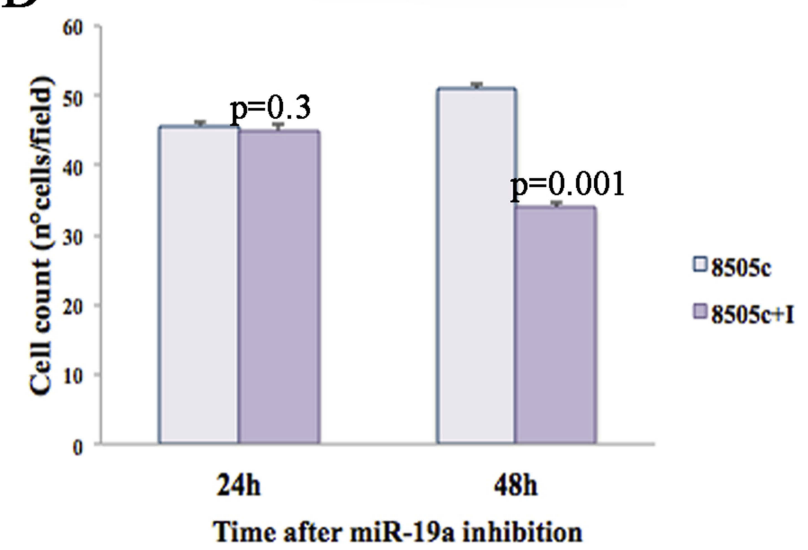

Figure 3 Effects of miR-19a inhibition on 8505 c cell morphology, proliferation, and viability. (A) Morphological analysis of control (A-B) and miR-19a downregulating (C-D) 8505 c cells, after 24 and 48 hrs. (B) Cell viability, assessed by MTT, of $8505 \mathrm{c}$ and $8505 \mathrm{c}+\mathrm{I}, 24$ and 48 hrs post-miR-19a inhibition. (C) Representative DAPI images showing the decrease of cell proliferation upon miR-19a inhibition (c, d) compared to control (a, b). (D) Average nuclei count in control (light violet) and mir-I9a downregulating cells (violet) 24 and 48 hrs after transfection.

The analyses of CDC25a and STK5 performed on 8505 c cells after miR-19a inhibition showed a statistically significant downregulation at both time points compared to both control and 24-hr groups, even if the decrease of CDC25a expression at $24 \mathrm{hrs}$ compared to the control was not significant (Figure 6A; CDC25a $24 \mathrm{hr} / \mathrm{ctr}_{-}$ $\mathrm{p}>0.05,48 \mathrm{hr} / \mathrm{ctr}$ and $48 \mathrm{hr} / 24 \mathrm{hr}{ }_{-}^{*}{ }^{*} \mathrm{p}<0.01$; STK5 $24 \mathrm{hr} /$ ctr and $\left.48 \mathrm{hr} / 24 \mathrm{hr}_{-}{ }^{*} \mathrm{p}<0.05,48 \mathrm{hr} / \mathrm{ctr}_{-}{ }^{*} \mathrm{p}<0.01\right)$. The gene expression profile of genes related to the thyroid differentiation showed a great expression variability in all examined genes at each time point with a predominant downregulation, except for $\mathrm{Tg}$, showing an upregulation at $48 \mathrm{hrs}(* * \mathrm{p}<0.01)$, compared to the control as well as at 24-hr group (Figure 6B).

The gene expression profile of poor prognosis-related genes displayed a statistically significant upregulation of CDH1 and a marked downexpression of S100A4 at each analyzed time point compared to the control and 24-hr groups (Figure $6 \mathrm{C} ;{ }^{* *} \mathrm{p}<0.01$ ).

\section{Discussion}

Recently a great number of findings have elucidated the pivotal role of miRNAs in the regulation of several cellular and biological processes including cell growth, differentiation, apoptosis, and metabolism. ${ }^{42}$ Despite the relevant number of evidences, a deeper understating of their direct functional involvement in pathological processes is needed in order to develop novel therapeutic strategies. Our results reveal the functional relationship between miR-19a and differentiation and proliferation pathways in thyroid cancer cells. Many investigations resulted in the identification of some miRNAs as fundamental controllers of the mechanisms underlying the development and progression of several types of cancer ${ }^{43}$ contributing to oncogenesis as tumor 


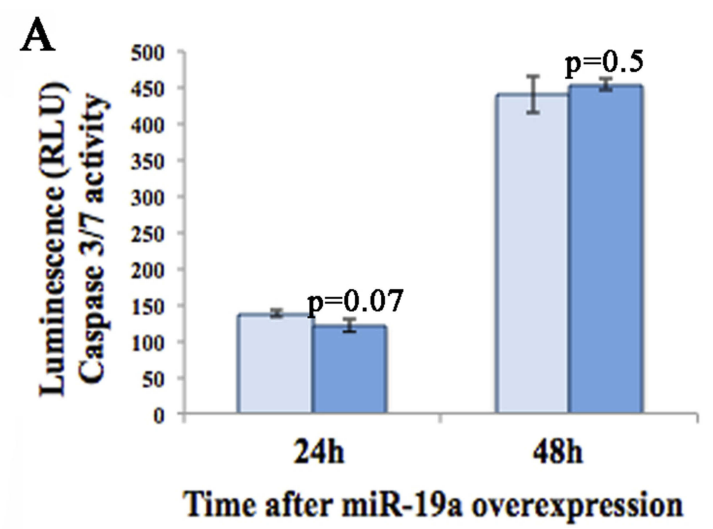

B

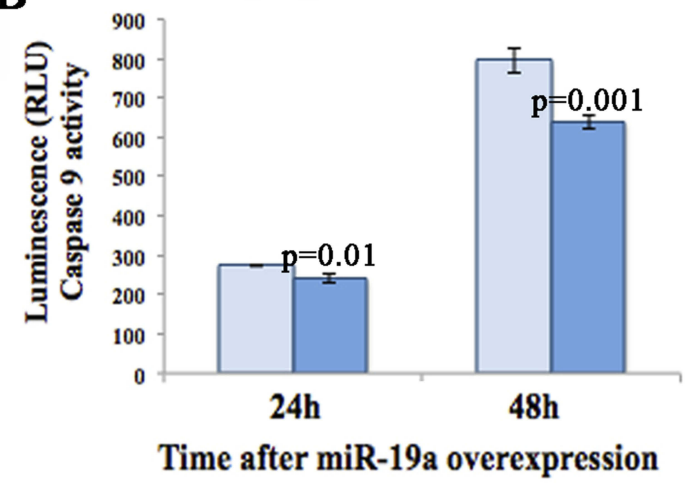

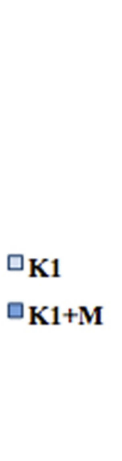

C

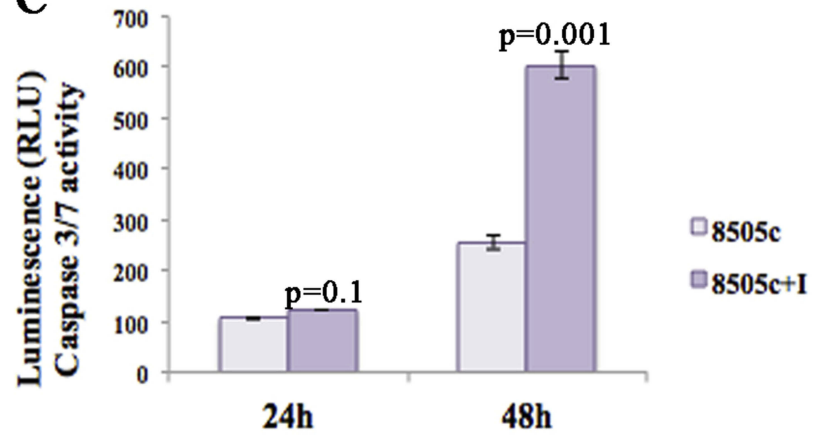

Time after miR-19a inhibition

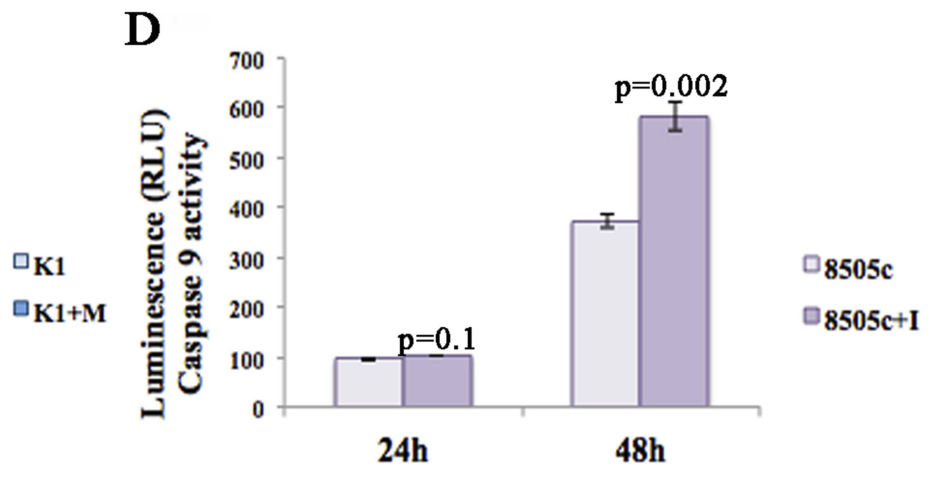

Time after miR-19a inhibition

Figure 4 Apoptosis assays of $\mathrm{KI}$ and 8505 c cells 24 and 48 hrs after miR-19a modulation. (A) Caspase-3/7 and (B) Caspase-9 activity of KI cells overexpressing miR-19a. (C) Caspase-3/7 and (D) Caspase-9 activity of 8505 c cells downregulating miR-19a, after 24 and 48 hrs. Activity is expressed in relative luminescence units (RLU). Each time point indicates the mean and SD of three independent experiments.

suppressor genes (let-7 family, miR-15a-16-1, and miR143-145 clusters) or as oncogenes (miR-155, miR-21, and miR-17-92 cluster). ${ }^{44}$ miR-17-92 cluster, also known as oncomir-1, yields a specific polycistronic primary transcript that generates six mature miRNAs, including miR-19a which plays a crucial role in mediating cluster oncogenic activity. ${ }^{28}$ In some recent studies, it was shown that miR19a was atypically expressed in malignant laryngeal carcinoma $^{45}$ and other forms of cancers, involving lung ${ }^{46}$ and gastric tumors. ${ }^{47}$ In addition, miR-19a expression was deeply correlated with malignancy invasion and metastasis and poor prognosis of lung tumor, ${ }^{48}$ osteosarcoma, ${ }^{49}$ and clear cell renal carcinoma patients ${ }^{50}$ by constitutively stimulating the NF- $\mathrm{BB}^{51}$ and PI3K/Akt or JAK/STAT signaling pathways. ${ }^{52-54}$ Since the involvement of miR-19a in the cellular phenotype of thyroid cancer cells was not previously investigated, the goal of this work was to assess the functional impact of its modulation in both PTC and ATC.

The results obtained in the present study suggest that the induction of miR-19a on PTC cells promotes a strong cell proliferation and viability. In contrast, miR-19a inhibition in ATC cells causes a robust reduction in cell growth and viability probably as results of the induction of the apoptotic process by activation of caspases. Since several evidences have already shown that PTEN is one of the known targets of miR-19a, it is also probable that miR-19a overexpression could be related to PTEN silencing stimulating cell proliferation in PTC, while its downexpression stimulates PTEN activation provoking cell growth decrease. Recently it has been suggested that PTEN inactivation is correlated with thyroid tumor progression and aggressiveness, particularly in ATC. ${ }^{55}$ These data together suggest that miR-19a induces an increased malignancy in well-differentiated thyroid cancer cells probably through stimulating cell proliferation and reducing apoptosis.

Furthermore, gene expression analysis on $\mathrm{K} 1$ cells at 24 and 48 hrs after miR-19a overexpression showed that genes and transcription factors involved in thyroid cell differentiation, such as TSHr, Tg, Pax8, and TTF1 $1^{56,57}$ were strongly downregulated thus highlighting that miR19a could be involved in the de-differentiated phenotype of thyroid cancer. In addition, also poor prognosis 


\section{Cell cycle genes}

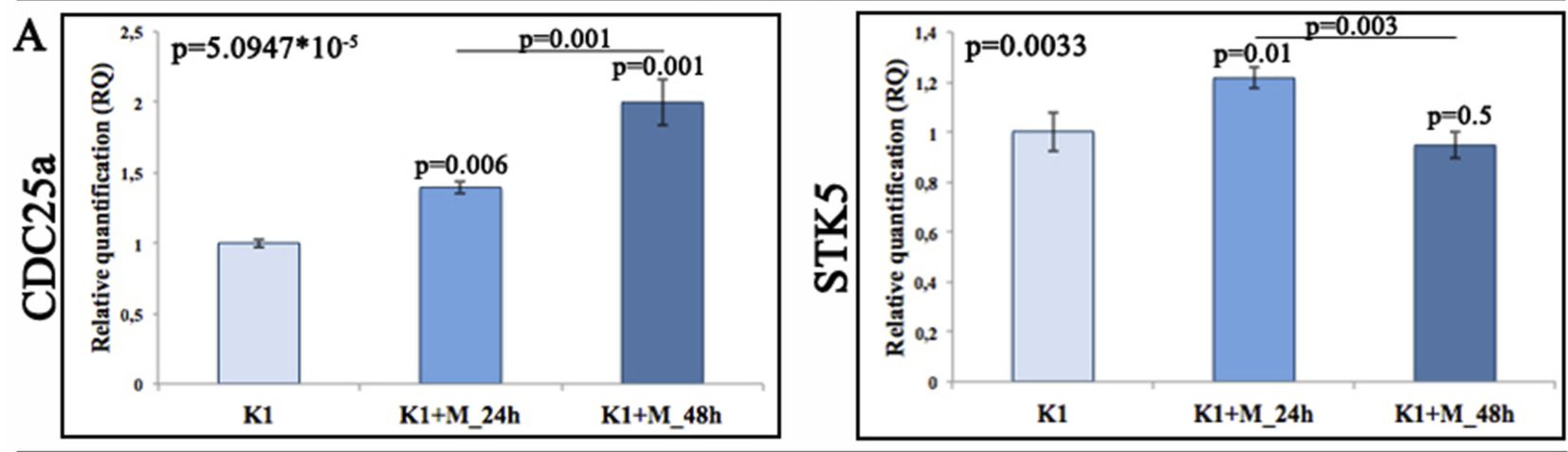

\section{Thyroid differentiation genes}
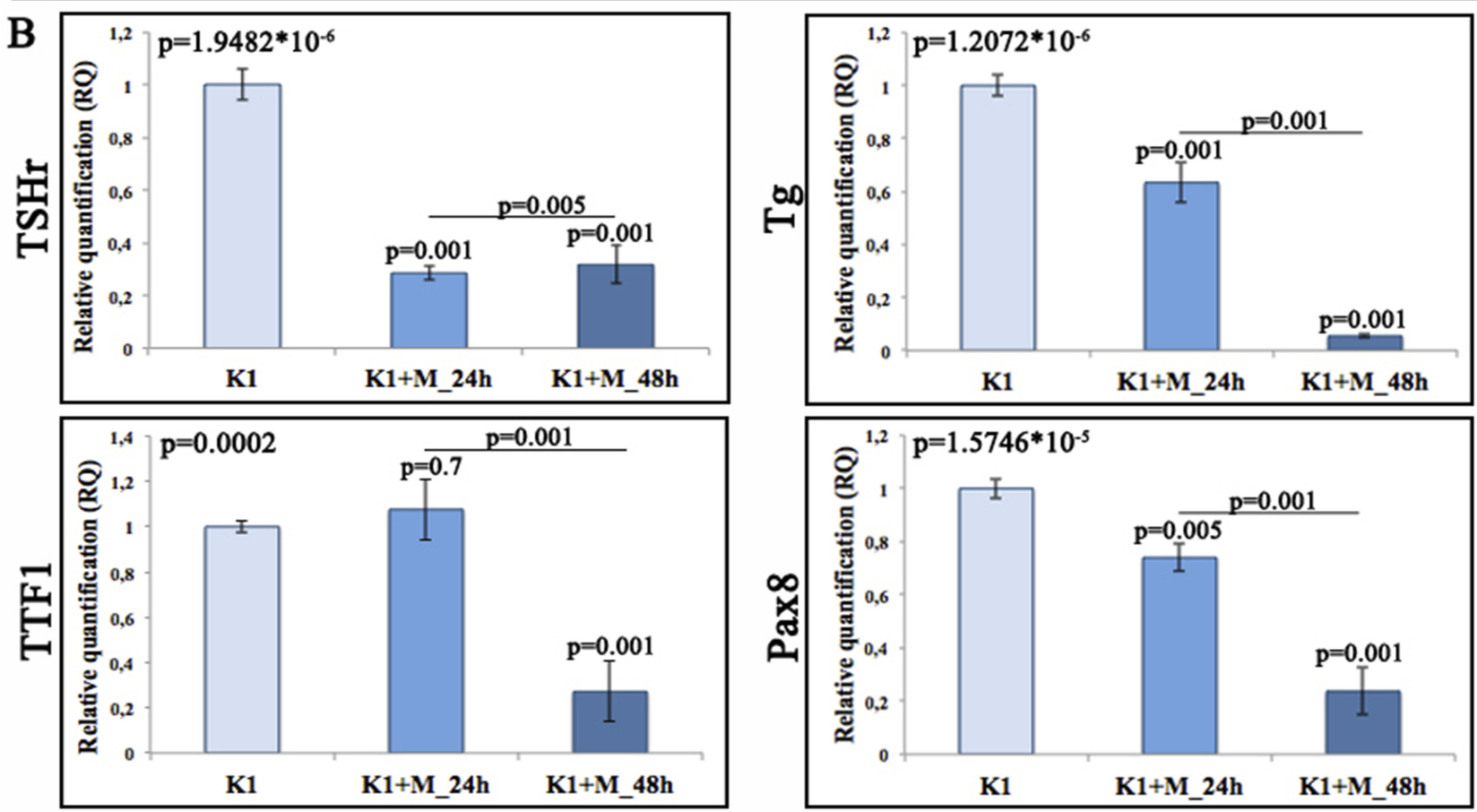

\section{Poor prognosis genes}
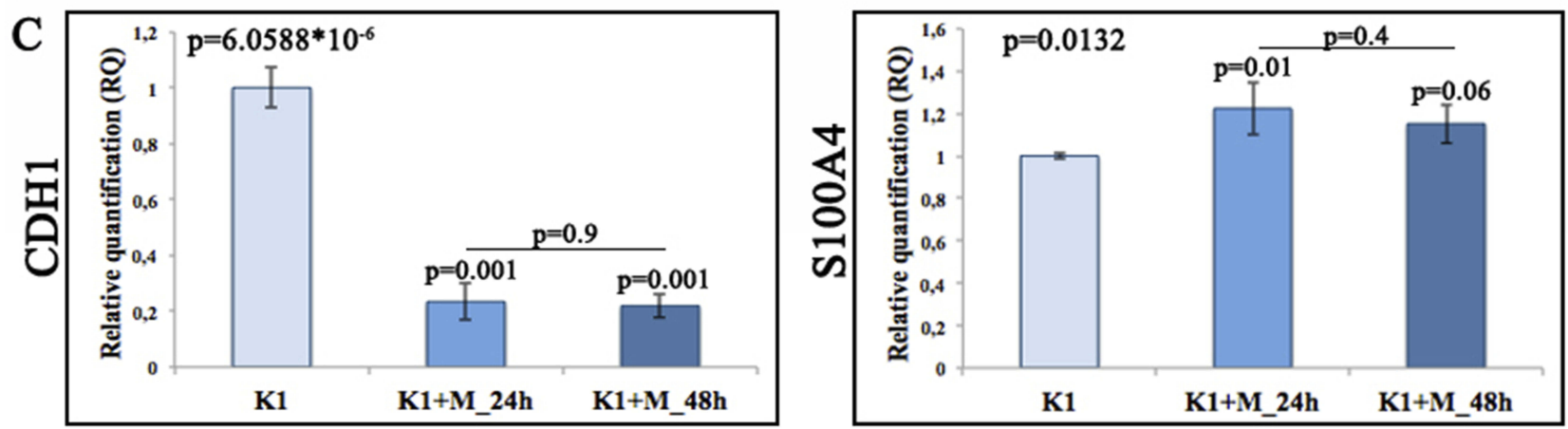

Figure 5 Gene expression profile on $\mathrm{KI}$ cells overexpressing miR-19a mimic. Relative quantitation of gene expression (RQ) showing the time-course of genes involved in (A) cell cycle; (B) thyroid differentiation, and (C) poor prognosis. GAPDH has been used as endogenous controls. 


\section{Cell cycle genes}

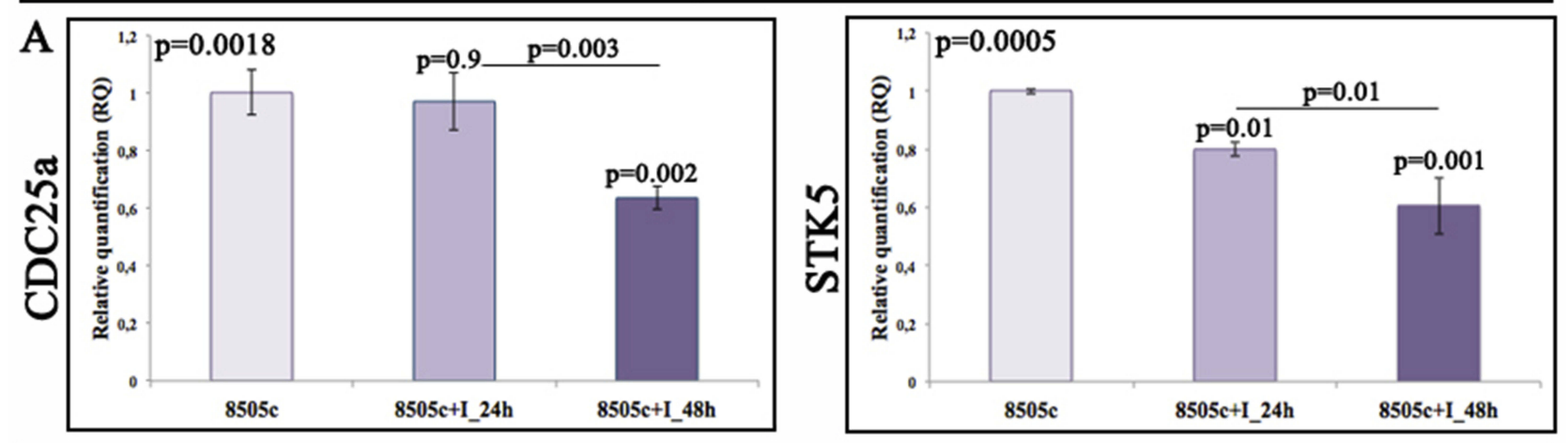

\section{Thyroid differentiation genes}
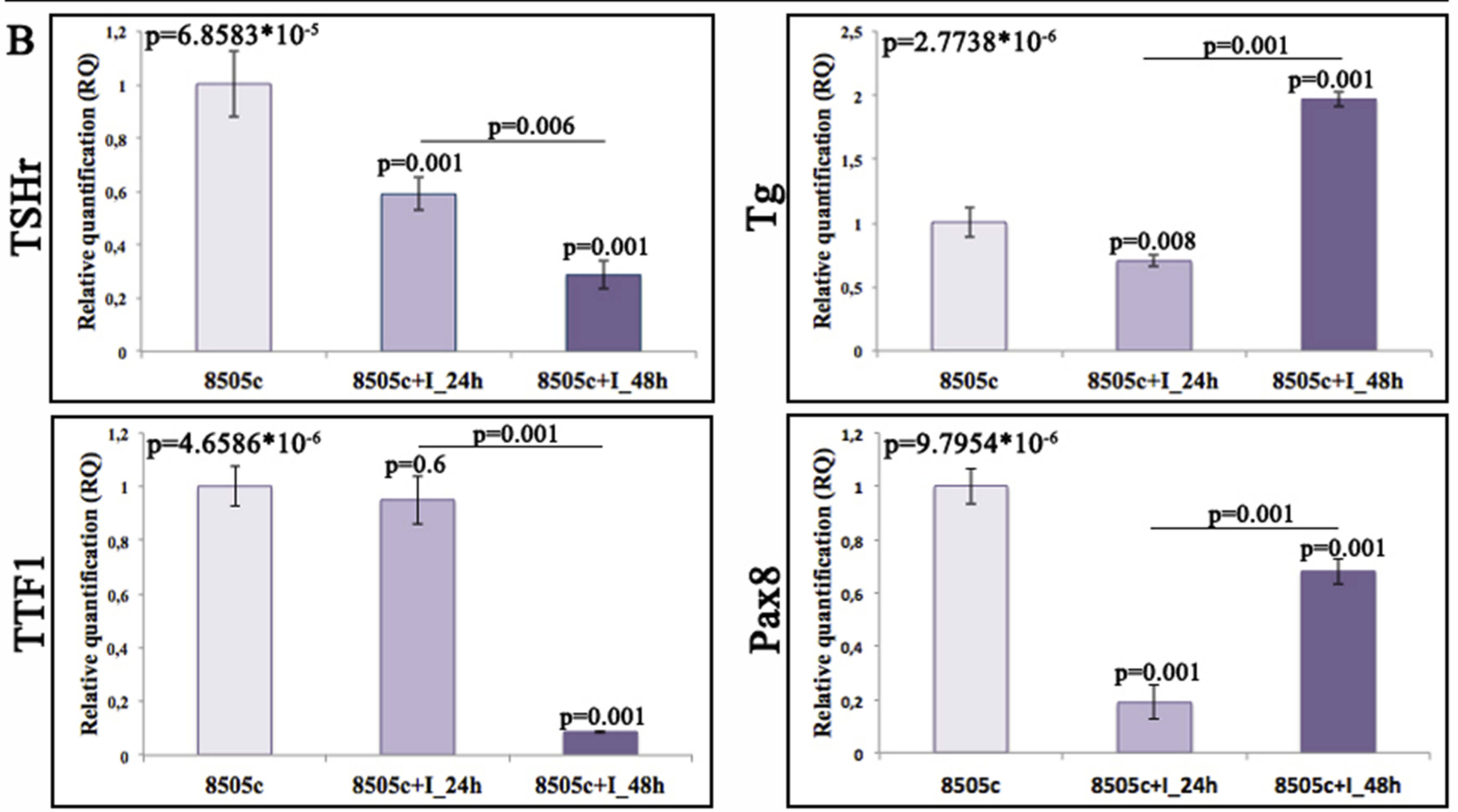

\section{Poor prognosis genes}
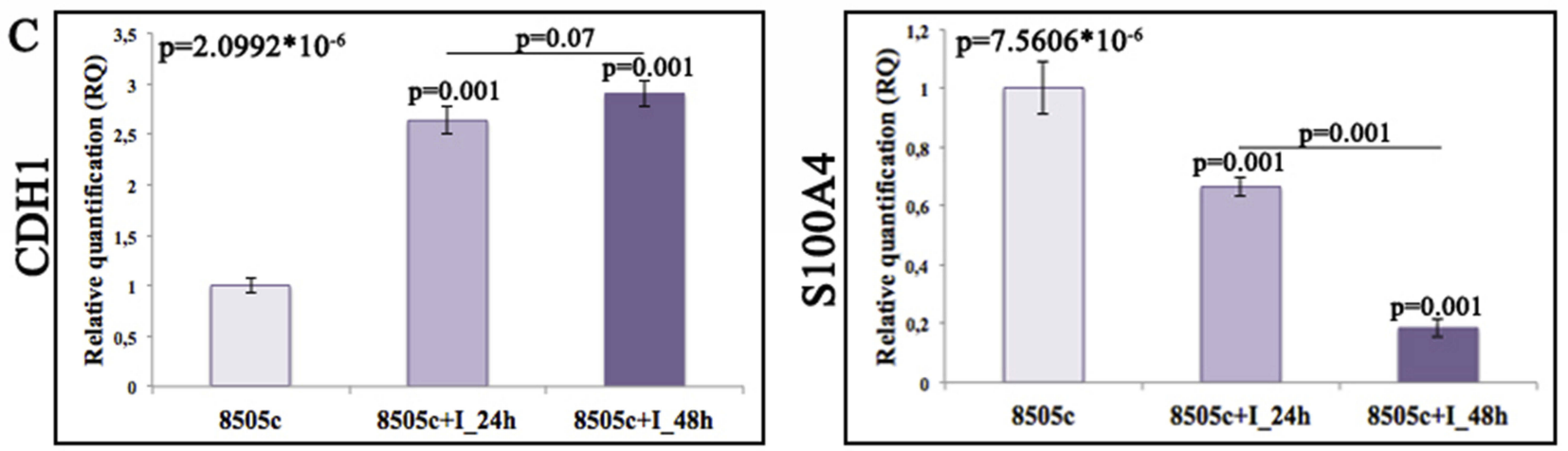

Figure 6 Gene expression profile on 8505 c cells after miR-19a inhibition. Relative quantitation of gene expression (RQ) showing the time-course of genes involved in (A) cell cycle; (B) thyroid differentiation, and (C) poor prognosis. GAPDH has been used as endogenous controls. 
genes ${ }^{58-61}$ showed a considerable deregulation, confirming our hypothesis on its possible role in the most aggressive thyroid cancer types. In contrast, our qRTPCR data performed on 8505c cells after miR-19a inhibition, at different time points, showed that this miRNA alone is not able to revert the de-differentiated phenotype of anaplastic tumor cells and acts only on S100A4 and $\mathrm{CDH} 1$, two poor prognosis genes involved in cell migration, proliferation, and invasion. ${ }^{60,61}$

The reported evidences support the hypothesis of a causative role for miR-19a in PTC de-differentiation and in the promoting of "poor prognosis" genes expression also if further studies in particular, on human tissues, are necessary to assess its suitability as new prognostic/ therapeutic markers for ATC.

\section{Acknowledgments}

This manuscript was supported by the Italian "Ministero dell'Istruzione, dell'Università e della Ricerca" grant PON03PE_00216_1 "Drug delivery: veicoli per un'innovazione sostenibile". A.D. was supported by a research fellowship no. 4676/2017 from the Biometec, University of Catania, Italy.

\section{Author Contributions}

All authors had substantial contribution to the present work. Specifically, G.C. conceived the project, designed the experiments and wrote the paper; A.D. performed the experiments and wrote the paper; Gu.C. contributed to the cell viability test execution; S.F. conceived the project and revised the paper. G.C. and S.F. are also the corresponding authors. All authors contributed towards data analysis, drafting and critically revising the paper, gave final approval of the version to be published, and agreed to be accountable for all aspects of the work.

\section{Disclosure}

SF reports grants from the Italian Ministry of University and Research during the conduct of the study. The authors confirm that they have no other conflicts of interest in this work.

\section{References}

1. Bartel DP. MicroRNAs: genomics, biogenesis, mechanism, and function. Cell. 2004;116(2):281-297. doi:10.1016/S0092-8674(04)00045-5

2. Lewis BP, Burge CB, Bartel DP. Conserved seed pairing, often flanked by adenosines, indicates that thousands of human genes are microRNA targets. Cell. 2005;120:15-20. doi:10.1016/j.cell.2004.12.035
3. Esquela-Kerscher A, Slack FJ. Oncomirs - microRNAs with a role in cancer. Nat Rev Cancer. 2006;6:259-269. doi:10.1038/nrc1840

4. Garofalo M, Condorelli GL, Croce CM, Condorelli G. MicroRNAs as regulators of death receptors signaling. Cell Death Differ. 2010;17 (2):200-208. doi:10.1038/cdd.2009.105

5. Garofalo M, Quintavalle C, Romano G, et al. miR221/222 in cancer: their role in tumor progression and response to therapy. Curr Mol Med. 2012;12(1):27-33. doi:10.2174/156652412798376170

6. Michael SM, O' Connor SM, van Holst Pellekaan NG. Reduced accumulation of specific MicroRNAs in colorectal neoplasia. Mol Cancer Res. 2003;1(12):882-891.

7. Calin GA, Ferracin M, Cimmino A, et al. A microRNA signature associated with prognosis and progression in chronic lymphocytic leukemia. N Engl J Med. 2005;353:1793-1801. doi:10.1056/NEJMoa050995

8. Yanaihara N, Caplen N, Bowman E, et al. Unique microRNA molecular profiles in lung cancer diagnosis and prognosis. Cancer Cell. 2006;9(3):189-198. doi:10.1016/j.ccr.2006.01.025

9. Iorio MV, Ferracin M, Liu C-G, et al. MicroRNA gene expression deregulation in human breast cancer. Cancer Res. 2005;65(16):70657070. doi:10.1158/0008-5472.CAN-05-1783

10. Ciafrè SA, Galardi S, Mangiola A, et al. Extensive modulation of a set of microRNAs in primary glioblastoma. Biochem Biophys Res Commun. 2005;334(4):1351-1358. doi:10.1016/j.bbrc.2005.07.030

11. Wang L, Liu C, Li C, et al. Effects of microRNA- 221/222 on cell proliferation and apoptosis in prostate cancer cells. Gene. 2015;572 (2):252-258. doi:10.1016/j.gene.2015.07.017

12. Xia JT, Chen LZ, Jian WH, et al. MicroRNA362 induces cell proliferation and apoptosis resistance in gastric cancer by activation of NF- $\mathrm{KB}$ signaling. J Transl Med. 2014;12:33. doi:10.1186/1479-5876-12-33

13. Marini F, Luzi E, Brandi ML. MicroRNA role in thyroid cancer development. J Thyroid Res. 2011;2011:407123. doi:10.4061/2011/ 407123

14. Kozomara A, Griffiths-Jones S. miRBase: annotating high confidence microRNAs using deep sequencing data. Nucleic Acids Res. 2014;42 (Database issue):D68-D73. doi:10.1093/nar/gkt1181

15. Calin GA, Sevignani C, Dumitru CD, et al. Human microRNA genes are frequently located at fragile sites and genomic regions involved in cancers. Proc Natl Acad Sci U S A. 2004;101(9):2999-3004. doi:10. 1073/pnas.0307323101

16. He L, Thomson JM, Hemann MT, et al. A microRNA polycistron as a potential human oncogene. Nature. 2005;435(7043):828-833. doi:1 0.1038 /nature 03552

17. O'Donnell KA, Wentzel EA, Zeller KI, et al. c-Myc-regulated microRNAs modulate E2F1 expression. Nature. 2005;435(7043):839843. doi: $10.1038 /$ nature 03677

18. Ota A, Tagawa H, Karnan S, et al. Identification and characterization of a novel gene, C13orf25, as a target for 13q31-q32 amplification in malignant lymphoma. Cancer Res. 2004;64(9):3087-3095. doi:10.11 58/0008-5472.CAN-03-3773

19. Hayashita Y, Osada H, Tatematsu Y, et al. A polycistronic microRNA cluster, miR-17-92, is overexpressed in human lung cancers and enhances cell proliferation. Cancer Res. 2005;65(21):9628-9632. doi:10.1158/0008-5472.CAN-05-2352

20. Volinia S, Calin GA, Liu CG, et al. A microRNA expression signature of human solid tumors defines cancer gene targets. Proc Natl Acad Sci U S A. 2006;103(7):2257-2261. doi:10.1073/pnas.0510565 103

21. Schulte JH, Horn S, Otto T, et al. MYCN regulates oncogenic MicroRNAs in neuroblastoma. Int J Cancer. 2008;122(3):699-704. doi:10.1002/ijc. 23153

22. Cloonan N, Brown MK, Steptoe AL, et al. The miR-17-5p microRNA is a key regulator of the G1/S phase cell cycle transition. Genome Biol. 2008;9(8):R127. doi:10.1186/gb-2008-9-8-r127

23. Tian B, Maidana DE, Dib B, et al. miR-17-3p exacerbates oxidative damage in human retinal pigment epithelial cells. PLoS One. 2016;11 (8):e0160887. doi:10.1371/journal.pone.0160887 
24. Takakura S, Mitsutake N, Nakashima M, et al. Oncogenic role of miR-17-92 cluster in anaplastic thyroid cancer cells. Cancer Sci. 2008;99(6):1147-1154. doi:10.1111/j.1349-7006.2008.00800.x

25. Xu X, Jiang YH, Feng JG, et al. MicroRNA-17, microRNA-18a, and microRNA-19a are prognostic indicators in esophageal squamous cell carcinoma. Ann Thorac Surg. 2014;97(3):1037-1045. doi:10.1016/j. athoracsur.2013.10.042

26. Huang G, Chen X, Cai Y, et al. miR-20a-directed regulation of BID is associated with the TRAIL sensitivity in colorectal cancer. Oncol Rep. 2017;37(1):571-578. doi:10.3892/or.2016.5278

27. Xiong Y, Zhang L, Kebebew E. MiR-20a is upregulated in anaplastic thyroid cancer and targets LIMK1. PLoS One. 2014;9(5):e96103. doi:10.1371/journal.pone.0096103

28. Olive V, Bennett MJ, Walker JC, et al. miR-19 is a key oncogenic component of mir-17-92. Genes Dev. 2009;23(24):2839-2849. doi:10.1101/gad.1861409

29. Carlomagno F, Santoro M. Thyroid cancer in 2010: a roadmap for targeted therapies. Nat Rev Endocrinol. 2011;7(2):65-67. doi:10.10 38/nrendo.2010.232

30. Curado MP, Edwards B, Shin HR, et al, editors. Cancer Incidence in Five Continents. Lyon, France: IARC Scientific Publications N.160; 2007:Vol. IX.

31. Amoli MM, Yazdani N, Amiri P, et al. HLA-DR association in papillary thyroid carcinoma. Dis Markers. 2010;28(1):49-53. doi:10. 3233/DMA-2010-0683

32. Jonklaas J, Nogueras-Gonzalez G, Munsell M, et al. The impact of age and gender on papillary thyroid cancer survival. J Clin Endocrinol Metab. 2012;97(6):E878-E887. doi:10.1210/jc.2011-2864

33. Li JH, He ZH, Bansal V, Hennessey JV. Low iodine diet in differentiated thyroid cancer: a review. Clin Endocrinol (Oxf). 2016;84:312. doi:10.1111/cen. 12846

34. Iglesias ML, Schmidt A, Ghuzlan AA. Radiation exposure and thyroid cancer: a review. Arch Endocrinol Metab. 2017;61(2):180-187. doi:10.1590/2359-3997000000257

35. Patel KN, Shaha AR. Poorly differentiated and anaplastic thyroid cancer. Cancer Control. 2006;13(2):119-128. doi:10.1177/1073274806 01300206

36. Parenti R, Salvatorelli L, Magro G. Anaplastic thyroid carcinoma: current treatments and potential new therapeutic options with emphasis on TfR1/CD71. Int J Endocrinol. 2014;2014:685396. doi:10.1155/ 2014/685396

37. Calabrese G, Dolcimascolo A, Torrisi F, et al. MiR-19a overexpression in FTC-133 cell line induces a more de-differentiated and aggressive phenotype. Int J Mol Sci. 2018;19:3944. doi:10.3390/ ijms19123944

38. Vicari L, La Rosa C, Forte S, et al. Differential expression of two activating transcription factor 5 isoforms in papillary thyroid carcinoma. Onco Targets Ther. 2016;9:6225-6231. doi:10.2147/OTT.S113194

39. Vicari L, Calabrese G, Forte S, et al. Potential role of activating transcription factor 5 during osteogenesis. Stem Cells Int. 2016;2016:5282185. doi:10.1155/2016/5282185

40. Yang J, Gao T, Tang J, et al. Loss of microRNA-132 predicts poor prognosis in patients with primary osteosarcoma. Mol Cell Biochem. 2013;381(1-2):9-15. doi:10.1007/s11010-013-1677-8

41. Chen C, Ridzon DA, Broomer AJ, et al. Real-time quantification of microRNAs by stem-loop RT-PCR. Nucleic Acids Res. 2005;33(20): e179. doi:10.1093/nar/gni178

42. Nikiforova MN, Chiosea SI, Nikiforov YE. MicroRNA expression profiles in thyroid tumors. Endocr Pathol. 2009;20(2):85-91. doi:10.1007/s12022-009-9069-z

43. Calin GA, Dumitru CD, Shimizu M, et al. Frequent deletions and downregulation of micro-RNA genes miR15 and miR16 at 13q14 in chronic lymphocytic leukemia. Proc Natl Acad Sci USA. 2002;99:15524-15529. doi:10.1073/pnas.242606799
44. Zhang B, Pan X, Cobb GP, Anderson TA. microRNAs as oncogenes and tumor suppressors. Dev Biol. 2007;302(1):1-12. doi:10.1016/j. ydbio.2006.08.028

45. Marioni G, Agostini M, Cappellesso R, et al. miR-19a and SOCS-1 expression in the differential diagnosis of laryngeal (glottic) verrucous squamous cell carcinoma. J Clin Pathol. 2015;69(5):415-421. doi:10.1136/jclinpath-2015-203308

46. Li J, Yang S, Yan W, et al. MicroRNA-19 triggers epithelialmesenchymal transition of lung cancer cells accompanied by growth inhibition. Lab Invest. 2015;95:1056-1070. doi:10.1038/labinvest. 2015.76

47. Qin S, Ai F, Ji WF, et al. miR-19a promotes cell growth and tumorigenesis through targeting SOCS1 in gastric cancer. Asian Pac $J$ Cancer Prev. 2013;14(2):835-840. doi:10.7314/APJCP.2013.14.2. 835

48. Ma Q, Peng Z, Wang L, et al. miR-19a correlates with poor prognosis of clear cell renal cell carcinoma patients via promoting cell proliferation and suppressing PTEN/SMAD4 expression. Int J Oncol. 2016;49(6):2589-2599. doi:10.3892/ijo.2016.3746

49. Zou P, Ding J, Fu S. Elevated expression of microRNA19a predicts a poor prognosis in patients with osteosarcoma. Pathol Res Pract. 2017;213(3):194-198. doi:10.1016/j.prp.2016.12.020

50. Yang F, Wang H, Jiang Z, et al. MicroRNA-19a mediates gastric carcinoma cell proliferation through the activation of nuclear factorкB. Mol Med Rep. 2015;12:5780-5786. doi:10.3892/mmr.2015.4151

51. Li HW, Xie Y, Li F, et al. Effect of miR-19a and miR-21 on the JAK/ STAT signaling pathway in the peripheral blood mononuclear cells of patients with systemic juvenile idiopathic arthritis. Exp Ther Med. 2016;11:2531-2536. doi:10.3892/etm.2016.3188

52. Xie CY, Kong JR, Zhao CS, et al. Molecular characterization and function of a PTEN gene from Litopenaeus vannamei after Vibrio alginolyticus challenge. Dev Comp Immunol. 2016;59:77-88. doi:10.1016/j.dci.2016.01.004

53. Forte S, Pagliuca A, Maniscalchi ET, et al. Gene expression analysis of PTEN positive glioblastoma stem cells identifies DUB3 and Wee1 modulation in a cell differentiation model. PLoS One. 2013;8(12): e81432. doi:10.1371/journal.pone.0081432

54. Lewis BP, Shih I, Jones-Rhoades MW, et al. Prediction of mammalian microRNA targets. Cell. 2003;115(7):787-798. doi:10.1016/ S0092-8674(03)01018-3

55. Frisk T, Foukakis T, Dwight T, et al. Silencing of the PTEN tumor suppressor gene in anaplastic thyroid cancer. Genes Chromosomes Cancer. 2002;35:74-80. doi:10.1002/gcc.10098

56. Ma R, Latif R, Davies TF. Thyroid Follicle Formation and Thyroglobulin expression in multipotent endodermal stem cells. Thyroid. 2013;23(4):385-391. doi:10.1089/thy.2012.0644

57. Fabbro D, Di Loreto C, Beltrami CA, et al. Expression of thyroidspecific transcription factors TTF-1 and PAX-8 in human thyroid neoplasms. Cancer Res. 1994;54(17):4744-4749.

58. Yutaka Y, Endou Y, Kimura K, et al. Inverse expression of S100A4 and E-cadherin is associated with metastatic potential in gastric cancer. Clin Cancer Res. 2000;6(11):4234-4242.

59. Montero-Conde C, Martín-Campos JM, Lerma E, et al. Molecular profiling related to poor prognosis in thyroid carcinoma. Combining gene expression data and biological information. Oncogene. 2008;27:1554-1561. doi:10.1038/sj.onc.1210792

60. Zou M, Al-Baradie RS, Al-Hindi H, Farid NR, Shi Y. S100A4 (Mts1) gene overexpression is associated with invasion and metastasis of papillary thyroid carcinoma. Br J Cancer. 2005;93(11):1277-1284. doi: $10.1038 /$ sj.bjc. 6602856

61. Brabant G, Hoang-Vu C, Cetin Y, et al. E-cadherin: a differentiation marker in thyroid malignancies. Cancer Res. 1993;53(20):49874993. 


\section{Publish your work in this journal}

OncoTargets and Therapy is an international, peer-reviewed, open access journal focusing on the pathological basis of all cancers, potential targets for therapy and treatment protocols employed to improve the management of cancer patients. The journal also focuses on the impact of management programs and new therapeutic agents and protocols on patient perspectives such as quality of life, adherence and satisfaction. The manuscript management system is completely online and includes a very quick and fair peer-review system, which is all easy to use. Visit http://www.dovepress.com/ testimonials.php to read real quotes from published authors.

Submit your manuscript here: https://www.dovepress.com/oncotargets-and-therapy-journal 